Machinery \& Energetics. Journal of Rural Production Research. Kyiv. Ukraine. 2020, Vol. 11, No 3, 23-29

ISSN 2663-1334 (print), ISSN 2663-1342 (online), www.journals.nubip.edu.ua/index.php/Tekhnica

http://dx.doi.org/10.31548/machenergy2020.03.023

УДК 621.87

\title{
MODELING AND CALCULATION POWER SAVING MODES GRAIN DRYING MATERIALS UNDER ENERGY FIELDS
}

\author{
V. O. Hryshchenko
}

National University of Life and Environmental Sciences of Ukraine, Ukraine.

Speciality of article: 141 - electric power, electrical engineering and electromechanics.

Corresponding author: vldr@nubip.edu.ua.

Article history: Received-April 2020, Accepted-August 2020.

Bibl. 14, fig. 3, tabl. 0 .

Abstract. Storing grain quality materials in post harvest handling and storage is largely dependent on correctly implemented the drying process. In agricultural production mainly use costly convection dryer. The main share of wasteful energy consumption accounts for heat drying agent, some heat is lost to the environment through the working surface of the dryers and spent coolant. Ways to reduce these energy costs is to reduce the amount of drying agent in the process to the level necessary to absorb and remove moisture from the dryer and the working volume of the principles of targeted "delivery" of energy to vysushuyemoho material. Last principles successfully implemented using contactless energy supply of electromagnetic fields in a material exposure by microwave or infrared radiation. The article deals with the theoretical background processes of drying material in cyclic mode with infrared heating and high frequency electromagnetic field. The equations change over time settings grain material by heating using high frequency electromagnetic field or infrared light and ventilation in the grain does not allow heated air drying cycle count process. The algorithm calculating the overall process of drying cycle to determine rational modes of the process, providing minimize energy costs. The article deals with the theoretical background processes of drying material in cyclic mode with infrared heating and high frequency electromagnetic field. The equations change over time settings grain material by heating using high frequency electromagnetic field or infrared light and ventilation in the grain does not allow heated air drying cycle count process. The algorithm calculating the overall process of drying cycle to determine rational modes of the process, providing minimize energy costs. The article deals with the theoretical background processes of drying material in cyclic mode with infrared heating and high frequency electromagnetic field. The equations change over time settings grain material by heating using high frequency electromagnetic field or infrared light and ventilation in the grain does not allow heated air drying cycle count process. The algorithm calculating the overall process of drying cycle to determine rational modes of the process, providing minimize energy costs. The equations change over time settings grain material by heating using high frequency electromagnetic field or infrared light and

ventilation in the grain does not allow heated air drying cycle count process. The algorithm calculating the overall process of drying cycle to determine rational modes of the process, providing minimize energy costs. The equations change over time settings grain material by heating using high frequency electromagnetic field or infrared light and ventilation in the grain does not allow heated air drying cycle count process. The algorithm calculating the overall process of drying cycle to determine rational modes of the process, providing minimize energy costs.

Key words: infrared heating, microwave heating, ventilation, drying grain, cyclical drying.

\section{Introduction}

The problem of maintaining the quality of grain materials in post harvest handling and storage is largely dependent on correctly implemented the drying process [1]. Currently in agricultural production mainly use costly convection dryer [2]. The main share of wasteful energy consumption accounts for heat drying agent, some heat is lost to the environment through the working surface of the dryers and spent coolant [3]. Ways to reduce these energy costs is to reduce the amount of drying agent in the process to the level necessary to absorb and remove moisture from the dryer and the working volume of the principles of targeted "delivery" of energy to the material.

\section{Formulation of problem}

Last principles successfully implemented using contactless energy supply of electromagnetic fields in a material exposure by microwave or infrared radiation [4]. The prospects of using high frequency electromagnetic field (EMF SHF) and infrared (ICHV) during heat treatment and drying grain materials such as independent energy sources defined experimental results [5]. But the search combined methods of treating materials in which energy is supplied only to the material in an amount necessary to achieve a specific action (heating, remove surface moisture or internal) is very relevant and timely [6]. The prospects of using high frequency 
electromagnetic field (EMF SHF) and infrared (ICHV) during heat treatment and drying grain materials such as independent energy sources defined experimental results [7]. But the search combined methods of treating materials in which energy is supplied only to the material in an amount necessary to achieve a specific action (heating, remove surface moisture or internal) is very relevant and timely [8]. The prospects of using high frequency electromagnetic field (EMF SHF) and infrared (ICHV) during heat treatment and drying grain materials such as independent energy sources defined experimental results [9]. But the search combined methods of treating materials in which energy is supplied only to the material in an amount necessary to achieve a specific action (heating, remove surface moisture or internal) is very relevant and timely [10].

\section{Analysis of recent research results}

Viability use directional energy to obroblyuyemyy material, namely heating and drying processes through targeted energy supply ultra high frequency electromagnetic radiation is described in [11].

The implementation process of microwave drying grain in specific units described in publications [12].

Energy and technological feasibility of energy of ultrahigh frequency electromagnetic field to intensify the drying process grounded in [11-13].

Question mathematical description and calculation drying processes discussed in scientific studies [14].

Analysis of publications [10, 12, 14] proved the effectiveness and drying cycle pulsed electromagnetic field on the material. But research in theoretical terms no matter the mathematical description of the combinedcycle drying grain materials.

\section{Purpose of research}

The purpose of the study is form a simplified model of the mathematical description of the process of cyclic heat treatment and drying grain material to determine energy efficient modes of infrared and microwave systems processing grain material.

\section{Results of research}

Experience in carrying out lifting works testifies that In general, the processes of heat transfer and mass in capillary-porous bodies terms of microwave and infrared heating system describing two or three differential equations. A. Lykov a partial, solution of which is considerable difficulty in practically useful forms can be obtained only by numerical methods. Since the solution of difficulties associated with the process parameters at rozpodilenistyu gradient forms of transport, using the approximate concentration hyphenation volume can be obtained analytical solutions for specific processing conditions of the product. Considering loose (particulate) material that moves or is moved in a thin (1-3 grains) for which microwave or infrared heating can be considered uniform in volume corns can be greatly simplified description of the process of heating and drying taking these simplifying assumptions:

gradients of temperature and humidity are so small that they can be ignored and considered medium volume temperature value $\theta_{c}(\tau)$ and humidity $U(\tau)$ material,

excess pressure in the capillaries of the material caused by the effect of EMF is a function of the temperature of the material and recorded via the temperature dependence of mass transfer coefficient (drying),

existing patterns of distribution of the radiation absorbed in the thickness of the material can also be averaged by volume (thickness) assuming uniform heating.

Under such conditions, the solution interrelated equations of heat and mass transfer leads to the integral equation heat transfer Alexander Lykov [11]:

$$
q_{f}(\tau)=r \rho_{0} R_{v} \frac{d U_{c}}{d \tau}+\rho_{0} R_{v} C \frac{d \theta_{c}}{d \tau},
$$

where: $R_{v}=V / F-$ hydraulic radius, $V$ - volume (particle layer), $F$ - surface, $\rho_{0}$ - density completely dry body, $C-$ specific heat, $r$ - enthalpy of vaporization, $\theta, U-$ temperature and moisture content of the material, $q(\tau)-$ average heat flux through the surface material.

Dividing all the members of (1) to obtain $R_{v}$ :

$$
q_{v}(\tau)=r \rho_{0} \frac{d U}{d \tau}+\rho_{0} C \frac{d \bar{\theta}}{d \tau},
$$

where: $q_{v}(\tau)$ - specific volumetric thermal output.

The values of $q_{f}(\tau)$ and $q_{v}(\tau)$ - defined by the known formulas $[11,13]$ for IR energy supply:

$$
\begin{aligned}
& q_{f}(\tau)=A_{\lambda} \sigma_{0} c_{n p}\left[\left(\frac{T_{1}}{100}\right)^{4}-\left(\frac{T_{2}}{100}\right)^{4}\right], \\
& q_{v}(\tau)=0.555 \cdot 10^{-10} \varepsilon^{\prime} f E^{2} \operatorname{tg} \delta,
\end{aligned}
$$

where: $\mathrm{c}_{\mathrm{np}}=\left(\varepsilon_{1}^{-1}+\varepsilon_{2}^{-1}-1\right)^{-1}-$ shows the emissivity of, $\varepsilon_{1}, \varepsilon_{2}$ - degree heat emissivity surfaces, $\sigma_{0}$ - was the StefanBoltzmann, $A_{\lambda}-$ absorption coefficient of the material infrared rays, $\varepsilon^{\prime}-$ dielectric permeability, $\operatorname{tg} \delta$ dissipation factor, $f, E$ - the frequency and intensity of the electromagnetic field.

Repeat grain drying material provides for periodic heating of grain microwave source material, followed by blowing air layer material (with heating and without heating). To determine the outpouring of heat exposure of the material and the length of its forced ventilation (blowing) without heating and hot air drying for basic characteristics (temperature and humidity of the material during heating and purging) and the total time periodic review process mode setting and continuous.

For the entire volume of the material (in the chamber drying) process of heating the internal power source $P$ $(P=N \eta$, where $\mathrm{N}-$ power microwave sources of EMF, $\eta-$ efficiency Megatron) in the presence of heat exchange between the material and still air in the chamber heat balance equation look like:

$$
\rho_{0} V_{m} c_{m} \frac{d \theta}{d \tau}-\rho_{0} r V_{m} \frac{d U}{d \tau}+\alpha f(\theta-t)=P,
$$




$$
\rho_{v} V_{v} c_{v} \frac{d t}{d \tau}=\alpha f(\theta-t)
$$

where: $V_{m}, V_{v}$ - the volume of material and the air in the chamber, $c_{m}, c_{v}$ - specific heat of the material and air, $\alpha-$ heat transfer coefficient, $\theta, t-$ the temperature of the material and air.

For closure system (4)-(5) equations, using criteria Rehbinder $R b=c d \theta / r d U$, obtain the equation of communication:

$$
-\frac{d U}{d \tau}=\frac{c}{r R b} \frac{d \theta}{d \tau}
$$

Substituting the value of $d U / d \tau$ in equation (4) and solving (4) and (5) in the initial conditions: $\tau=0, t=t_{0}$, $\theta=\theta_{0}$, we get:

$$
\theta(\tau)=\theta_{0}+\frac{Q}{B} \tau-\frac{A}{B}\left(\frac{Q}{B}-T_{0}\right)\left(1-e^{-\frac{B}{A} \tau}\right),
$$

where: $Q=P / \alpha F, A=\left(m c^{\prime} m_{v} c_{p}\right) /(\alpha F)^{2}, \quad B=\left(m c+m_{v} c_{p}\right) / \alpha F$, $c^{\prime}=c\left(1+R b^{-1}\right), T_{0}=(P / m c)+(\alpha F / m c)\left(t_{0}-\theta_{0}\right)$.

The equation describes the change in temperature of the grain material during heating in the microwave EMF. Using the experimentally obtained dependence [6] The moisture content of the criterion Rehbinder material: $R b(U)=R_{0} e^{a U}$ rewrite equation (6) as:

$$
R_{0} e^{a U} \frac{d U}{d \tau}=\frac{c}{r} \frac{d \theta}{d \tau}
$$

Prodifferentiative dependence $\theta(\tau)$ and substituting the value obtained in equation (6a) after differentiation within $U 1 \rightarrow U, 0 \rightarrow \tau$ get:

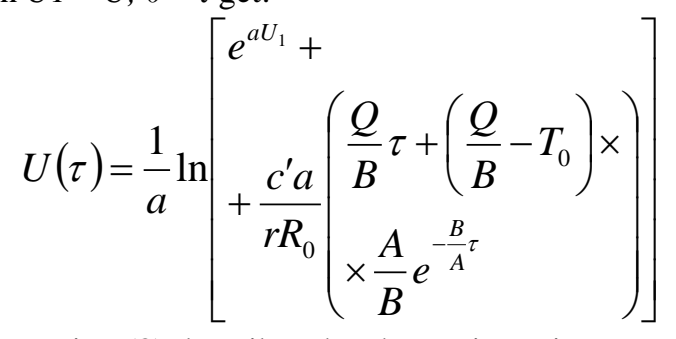

Equation (8) describes the change in moisture content in the process of heat when exposed to EMF MVCH.

During the heated grain ventilation air temperature at the inlet of the layer $t 1$ heat balance equation is written as

$$
G_{v} c_{p} \eta\left(t_{1}-\theta\right)=c^{\prime} m \frac{d \theta}{d \tau},
$$

where: $\quad \eta=\left(t_{1}-t_{2}\right) /\left(t_{1}-\theta\right)=1-\exp \left(-\alpha F / G_{v} c_{p}\right), \quad t_{1}, \quad t_{2} \quad-$ the temperature of the input and output layers of the grain material.

Changing moisture Alexander Lykov by the formula:

$$
-\frac{d U}{d \tau}=k(\theta)\left(U-U_{p}\right)
$$

Solution equation (9) with the initial conditions: $\tau=0$, $\theta=\theta_{0}$, will look like:

$$
\theta(\tau)=t_{1}+\left(\theta_{0}-t_{1}\right) e^{-\frac{\tau}{T}}
$$

where: $T=c^{\prime} m / G_{v} c_{p} \eta$.

Using linear approximation dependence of drying temperature: $k(\theta)=k_{l} \theta$ of equations (10) and (11) we get:

$$
\frac{d U}{d \tau}=k_{1}\left[t_{1}+\left(\theta_{0}-t_{1}\right) e^{-\frac{\tau}{T}}\right] d \tau
$$

Integrating the conditions: $\tau=0, \quad U=U_{0}$ after transformations have:

$$
\begin{aligned}
& U(\tau)=U_{p}+ \\
& +\left(U_{1}-U_{p}\right) \exp \left(k_{1} t_{1} \tau-\left(\theta_{0}-t_{1}\right) T e^{-\frac{\tau}{T}}\right) .
\end{aligned}
$$

Equation (13) describes zmine moisture content of grain heated during ventilation.

For continuous process using equation $(7,8)$ and $(11$, 13) replacing $\tau=x V^{-1}$ (where $V$ - the velocity of the material, $x$ - coordinate direction of the material). At the zonal method of calculation equations replace $\Delta \tau_{i}=\Delta x_{i} V^{-1}$.

The equations change over time settings grain material when heated in the microwave EMF and with aeration of grain not allow heated air drying cycle count process as follows (Fig. 1).

When using moist heat radiation in the infrared material equation (4) the value of the power source, define internal formula (3) and rewrite it as:

$$
\begin{aligned}
& A_{\lambda} c_{n p}^{\prime} 10^{-8}\left(T_{1}^{4}-T_{2}^{4}\right) F_{w}=m_{m} c_{m} \frac{d \theta}{d \tau}- \\
& -m_{m 0} r \frac{d U}{d \tau}+\alpha f(\theta-t)
\end{aligned}
$$

For analytical solution of the system (3) - (4a) linearizes the left part of the equation (4a) using a [13] linear coefficient of heat transfers by radiation:

$$
\alpha_{l}=c_{n p}^{\prime} 10^{-8}\left(T_{1}^{2}+T_{2}^{2}\right)+\left(T_{1}+T_{2}\right),
$$

and therefore substitution:

$$
A_{\lambda} c_{n p}^{\prime} 10^{-8}\left(T_{1}^{4}-T_{2}^{4}\right) F_{w}=\alpha_{l} F_{w}\left(\theta_{w}-\theta\right),
$$

where: $T_{1}=273+\theta_{w}, T_{2}=273+\theta, \theta_{w}-$ radiator heating temperature in steady state (after warming up).

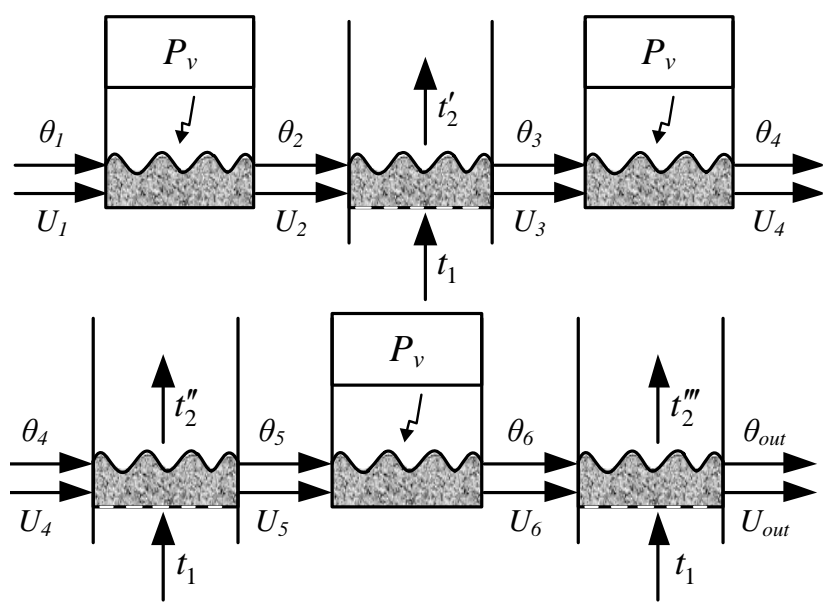

Fig. 1. The scheme of calculating the cyclical drying grain material.

Рис. 1. Схема розрахунку циклічного висихання зернового матеріалу.

We write the equation of kinetics heating material and ambient air chambers in the form of: 


$$
\begin{aligned}
& T_{1} \frac{d \theta}{d \tau}+a_{1} \theta-b_{1}=t \\
& T_{2} \frac{d t}{d \tau}+a_{2} t-b_{2}=\theta
\end{aligned}
$$

where: $\quad T_{1}=\frac{m_{m} c_{m}}{\alpha F+\alpha_{l} F_{w}}, \quad T_{2}=\frac{m_{p} c_{p}}{\alpha F}$, $a_{1}=\frac{\alpha F+\alpha_{l} F_{w}}{\alpha F}, b_{1}=\frac{\alpha_{l} F_{w}}{\alpha F} \theta_{w}, a_{2}=\frac{K F_{0}+\alpha F}{\alpha F}$, $b_{2}=\frac{K F_{0}}{\alpha F} t_{0}$.

Combining equations (14) and (15) to one that is relatively solving system $\theta(\tau)$ and $t(\tau)$ will have two equations:

$$
\begin{aligned}
& A \frac{d^{2} \theta}{d \tau^{2}}+B \frac{d \theta}{d \tau}+C \theta=D_{1}, \\
& A \frac{d^{2} t}{d \tau^{2}}+B \frac{d t}{d \tau}+C t=D_{2},
\end{aligned}
$$

where: $A=T_{1} T_{2}, \quad B=T_{1} a_{2}+T_{2} a_{1}, \quad C=\left(a_{1} a_{2}-1\right)$, $D_{1}=b_{2}+a_{2} b_{1}, D_{2}=b_{1}+a_{1} b_{2}$.

Solving ordinary differential equations (16) and (17) with the initial conditions: $\tau=0, \theta=\theta_{0}, t=t_{0}$, will have the following changes:

$$
\begin{aligned}
& \theta(\tau)=\frac{C \theta_{0}-D_{1}}{C\left(r_{1}-r_{2}\right)}\left[r_{1} e^{r_{2} \tau}-r_{2} e^{r_{1} \tau}\right]+\frac{D_{1}}{C}, \\
& t(\tau)=\frac{C t_{0}-D_{2}}{C\left(r_{1}-r_{2}\right)}\left[r_{1} e^{r_{2} \tau}-r_{2} e^{r_{1} \tau}\right]+\frac{D_{2}}{C} .
\end{aligned}
$$

Using experimental approximation criterion depending on humidity Rebinder $R b^{\prime}(U)$ Equations (6a) and derivative $d \theta(\tau) / d \tau$ (18):

$$
\frac{d \theta(\tau)}{d \tau}=K_{1} r_{1} r_{2}\left(e^{r_{2} \tau}-e^{r_{1} \tau}\right)
$$

drying kinetics equation we get:

$$
-R_{0}^{\prime} e^{a_{1} U} \frac{d U}{d \tau}=K_{1} r_{1} r_{2}\left(e^{r_{2} \tau}-e^{r_{1} \tau}\right) .
$$

Where $K_{1}=\frac{C \theta_{0}-D_{1}}{C\left(r_{1}-r_{2}\right)}$.

Solution of equation (20) with the initial conditions: $\tau=0, U=U_{0}$ :

$$
U(\tau)=\frac{1}{a_{1}} \ln \frac{a_{1}}{R_{0}}\left[\begin{array}{l}
\frac{R_{0}}{a_{1}} e^{a_{1} U_{0}}- \\
-K_{1} r_{2}\left(1-e^{r_{1} \tau}\right)+ \\
+K_{1} r_{1}\left(1-e^{r_{2} \tau}\right)
\end{array}\right] .
$$

Equation (21) determines the change in moisture content material with infrared irradiation temperature radiator $\theta_{w}=$ const in air temperature $t=$ const .
Changes in temperature and moisture content of the material at the heated grain aeration is determined by the equations (11) and (13).

The algorithm for calculating the cyclical drying process consists of sequential calculation curves heating and drying formulas (7), (8) for microwave irradiation, and the formulas (11), (13) calculated temperature change material and its moisture content mode ventilation layer material. The initial (input) values of the parameters $\theta_{l}(x)$ and $U_{l}(x)$ for each of the following areas will be the final parameters $\theta_{2}(x)$ and $U_{2}(x)$ the previous zone. For example, in the first zone of microwave heating in the direction of the grain bed just formulas (7) and (8) that are accepted in the diagram (Fig. 1) notation written in this form (with $0 \leq x \leq L_{1}, \quad x=L_{1}, \quad \theta_{1}(x)=\theta_{2}$, $\left.u_{1}(x)=u_{2}\right)$ :

$$
\begin{array}{r}
\theta_{1}(x)=\theta_{1}+\frac{Q}{B v} x-\frac{A}{B}\left(\frac{Q}{B}-T_{1}\right)\left(1-e^{-\frac{B}{v A} x}\right), \\
u_{1}(x)=\frac{1}{a} \ln \left[e^{a u_{1}}+\frac{c^{\prime} a}{r R_{0}}\left(\begin{array}{l}
+\frac{Q}{B v} x+ \\
+\left(\frac{A}{B}-T_{1}\right) \times \\
\left.\left.\times \frac{A}{B} e^{-\frac{B}{A v} x}\right)\right]
\end{array}\right.\right.
\end{array}
$$

For the next first zone ventilation (air filtration) kinetics equation heating and drying written in the form (in $0 \leq x \leq L_{2}, x=L_{2}, \theta_{1}^{\prime}(x)=\theta_{3}, u_{1}^{\prime}(x)=u_{3}$ ):

$$
\begin{gathered}
\theta_{1}^{\prime}(x)=t_{1}+\left(\theta_{2}-t_{1}\right) e^{-\frac{1}{v T} x}, \\
u_{1}^{\prime}(x)=u_{p}+\left(u_{2}-u_{p}\right) \times \\
\times \exp \left(k_{1} t_{1} x v^{-1}-\left(\theta_{2}-t_{1}\right) e^{-\frac{1}{v T} x}\right) .
\end{gathered}
$$

For the second zone microwave heating (with $\left.0 \leq x \leq L_{1}, x=L_{1}, \theta_{3}(x)=\theta_{4}, u_{3}(x)=u_{4}\right)$ :

$$
\theta_{2}(x)=\theta_{3}+\frac{Q}{B v} x-\frac{A}{B}\left(\frac{Q}{B}-\theta_{3}\right)\left(1-e^{-\frac{B}{v A} x}\right)
$$

$$
u_{2}(x)=\frac{1}{a} \ln \left[e^{a u_{3}}+\frac{c^{\prime} a}{r R_{0}}\left(\begin{array}{l}
\frac{Q}{B v} x+ \\
+\left(\frac{Q}{B}-\theta_{3}\right) \times \\
\times \frac{A}{B} e^{-\frac{B}{A v} x}
\end{array}\right)\right] .
$$

For the second aeration zone (at $0 \leq x \leq L_{2}$, $\left.x=L_{2}, \theta_{2}^{\prime}(x)=\theta_{5}, u_{2}^{\prime}(x)=u_{5}\right)$ :

$$
\theta_{2}^{\prime}(x)=t_{1}+\left(\theta_{4}-t_{1}\right) e^{-\frac{1}{v T} x},
$$




$$
\begin{aligned}
& u_{2}^{\prime}(x)=u_{p}+\left(u_{4}-u_{p}\right) \times \\
& \times \exp \left(k_{1} t_{1} x v^{-1}-\left(\theta_{4}-t_{1}\right) e^{-\frac{1}{v T} x}\right) .
\end{aligned}
$$

The third area of microwave heating (with $\left.0 \leq x \leq L_{1}, x=L_{1}, \theta_{3}(x)=\theta_{6}, u_{3}(x)=u_{6}\right)$ :

$$
\begin{aligned}
& \theta_{3}(x)=\theta_{5}+\frac{Q}{B v} x-\frac{A}{B}\left(\frac{Q}{B}-\theta_{5}\right)\left(1-e^{-\frac{B}{v A} x}\right), \\
& u_{3}(x)=\frac{1}{a} \ln \left[\begin{array}{l}
e^{a u_{4}}+\frac{c^{\prime} a}{r R_{0}} \times \\
\left.\times\left(\frac{Q}{B v} x+\left(\frac{Q}{B}-\theta_{5}\right) \frac{A}{B} e^{-\frac{B}{A v} x}\right)\right]
\end{array}\right.
\end{aligned}
$$

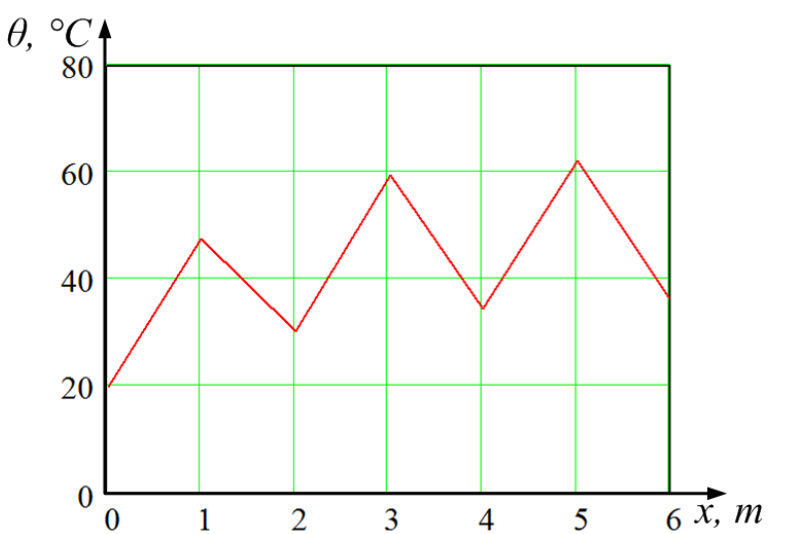

Fig. 2. Change the temperature grain drying under cyclic heating in the microwave power was 400 watts (weight $0.12 \mathrm{~kg}$ ) and ventilation air $21^{\circ} \mathrm{C}$.

Рис. 2. Зміна температури сушіння зерна при циклічному нагріванні в мікрохвильовій печі була потужністю 400 Вт (вага 0,12 кг) і вентиляції повітря $21{ }^{\circ} \mathrm{C}$.

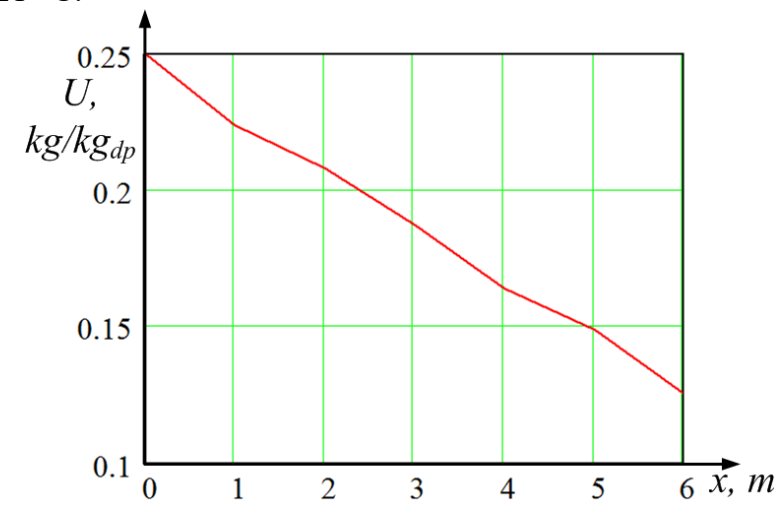

Fig. 3. Change the grain moisture content during the drying cycle.

Рис. 3. Зміна вмісту вологи в зерні протягом циклу сушіння.

For the third venting zone (at $0 \leq x \leq L_{2}, x=L_{2}$, $\left.\theta_{3}^{\prime}(x)=\theta_{\text {out }}, u_{2}^{\prime}(x)=u_{\text {out }}\right)$ :

$$
\theta_{3}^{\prime}(x)=t_{1}+\left(\theta_{6}-t_{1}\right) e^{-\frac{1}{v T} x}
$$

$$
\begin{aligned}
& u_{3}^{\prime}(x)=u_{p}+\left(u_{6}-u_{p}\right) \times \\
& \times \exp \left(k_{1} t_{1} x v^{-1}-\left(\theta_{4}-t_{1}\right) e^{-\frac{1}{v T} x}\right) .
\end{aligned}
$$

where: $\theta_{\text {out }}, u_{\text {out }}-$ final temperature and moisture content of the material.

Fig. 2-3. is shown graphic changes depending on parameters of drying cycle.

\section{Conclusions}

1. As a result of theoretical research formulated a mathematical model of drying material in cyclic mode and simplified formula for calculating the heating and drying process using microwave heating and infrared heating.

2. Algorithm for calculating the overall process of drying cycle to determine rational modes of the process, providing minimize energy costs.

\section{References}

1.Bogaert L., Mathieu H., Mhemdi H., Vorobiev E. (2018). Characterization of oilseeds mechanical expression in an instrumented pilot screw press. Industrial Crops and Products. 121. 106-113.

2.Dobrin D., Magureanu M., Mandache N., Ionita M. (2015). The effect of non-thermal plasma treatment on wheat germination and early growth. Innovative Food Science \& Emerging Technologies. 29. 255-260. https://doi.org/10.1016/j.ifset.2015.02.006.

3.Gorji A., Rajabipour A., Tavakoli H. (2010). Fracture resistance of wheat grain as a function of moisture content, loading rate and grain orientation. Australian Journal of Crop Science. 4. 448-452.

4.Kotov B., Kalinichenko R., Spirin A. (2015). Mathematical modeling of heat and mass transfer process under heat treatment of grain materials in dense layer. TEKA. Commission of Motorization and Energetics in Agriculture. 17(5). 54-57.

5.Kotov B. I., Spirin A. B., Tverdokhlib I. V., Polyevoda Y. A., Hryshchenko V. O., Kalinichenko R. A. (2018). Theoretical researches of cooling process regularity of the grain material in the layer. INMATEH: Agricultural Engineering. 54(1). 87-94.

6.Kroulik M., Húla J., Rybka A., Honzík I. (2016). Pneumatic conveying characteristics of seeds in a vertical ascending airstream. Research in Agricultural Engineering. 62(2). 56-63.

7. Kuznetsov $Y$. A.,

Volzhentsev A. V., Kolomeichenko A. V., Kalashnikova L. V. (2017). Grounding of construction parameters of pseudofluidized layer dryer working chamber. INMATEH: Agricultural Engineering. 52(2). 33-38.

8. Rogovskii I. L., Palamarchuk I. P., Kiurchev S. V., Verkholantseva V. O., Voinash S. A., Sokolova V. A., Gogolevski A.S. (2020). Mathematical modeling of the impulse bubbling process of bulk mass by the coolant flow. IOP Conference Series: Materials Science and 
Engineering. 919. 052026. doi:10.1088/1757-899X/919/5/ 052026.

9.Rogovskii I. L., Stepanenko S. P., Novitskii A. V., Rebenko V.I. (2020). The mathematical modeling of changes in grain moisture and heat loss on adsorption drying from parameters of grain dryer. IOP Conference Series: Earth and Environmental Science. 548. 082057 doi:10.1088/1755-1315/548/8/082057.

10. Kuznetsov Y. A.,

Volzhentsev A. V., Kolomeichenko A. V., Kalashnikova L. V. (2018). Influence of technological parameters of pseudofluidized layer grain dryer on the grain drying quality. INMATEH: Agricultural Engineering. 54(1). 81-86.

11. Lukaszuk J., Molenda M., Horabik J., Szot B., Montross M. (2008). Air flow resistance of wheat bedding as influenced by the filling method. Research in Agricultural Engineering. 54(2). 50-57.

12. Rogovskii I. L., Titova L. L., Trokhaniak V. I., Solomka O. V., Popyk P. S., Shvidia V. O., Stepanenko S. P. (2019). Experimental studies of drying conditions of grain crops with high moisture content in low-pressure environment. INMATEH. Agricultural Engineering. Bucharest. 57(1). 141-146.

13. Paziuk V. M., Liubin M. V., Yaropud V. M., Tokarchuk O. A., Tokarchuk D. M. (2018). Research on the rational regimes of wheat seeds drying. INMATEH: Agricultural Engineering. 56(3). 39-48.

14. Rekas A., Scibisz I., Siger A., Wroniak M. (2017). The effect of microwave pre-treatment of seeds on the stability and degradation kinetics of phenolic compounds in rapeseed oil during long-term storage. Food Chemistry. 222. 43-52.

\section{Список літератури}

1.Bogaert L., Mathieu H., Mhemdi H., Vorobiev E. Characterization of oilseeds mechanical expression in an instrumented pilot screw press. Industrial Crops and Products. 2018. Vol. 121. P. 106-113.

2.Dobrin D., Magureanu M., Mandache N., Ionita M. The effect of non-thermal plasma treatment on wheat germination and early growth. Innovative Food Science \& Emerging Technologies. 2015. Vol. 29. P. 255-260. https://doi.org/10.1016/j.ifset.2015.02.006.

3.Gorji A., Rajabipour A., Tavakoli H. Fracture resistance of wheat grain as a function of moisture content, loading rate and grain orientation. Australian Journal of Crop Science. 2010. Vol. 4. P. 448-452.

4.Kotov B., Kalinichenko R., Spirin A. Mathematical modeling of heat and mass transfer process under heat treatment of grain materials in dense layer. TEKA. Commission of Motorization and Energetics in Agriculture. 2015. Vol. 17, Issue 5. P. 54-57.

5.Kotov B. I., Spirin A. B., Tverdokhlib I. V., Polyevoda Y. A., Hryshchenko V. O., Kalinichenko R. A. Theoretical researches of cooling process regularity of the grain material in the layer. INMATEH: Agricultural Engineering. 2018. Vol. 54, no 1. P. 87-94.

6.Kroulik M., Húla J., Rybka A., Honzík I. Pneumatic conveying characteristics of seeds in a vertical ascending airstream. Research in Agricultural Engineering. 2016. Vol. 62, no. 2, P. 56-63.
7. Kuznetsov Y. A., Volzhentsev A. V., Kolomeichenko A. V., Kalashnikova L. V. Grounding of construction parameters of pseudofluidized layer dryer working chamber. INMATEH: Agricultural Engineering. 2017. Vol. 52, no. 2. P. 33-38.

8.Rogovskii I. L., Palamarchuk I. P., Kiurchev S. V., Verkholantseva V. O., Voinash S. A., Sokolova V. A., Gogolevski A. S. Mathematical modeling of the impulse bubbling process of bulk mass by the coolant flow. IOP Conference Series: Materials Science and Engineering. 2020. vol. 919, 052026. doi:10.1088/1757899X/919/5/052026.

9.Rogovskii I. L., Stepanenko S. P., Novitskii A. V., Rebenko V.I. The mathematical modeling of changes in grain moisture and heat loss on adsorption drying from parameters of grain dryer. IOP Conference Series: Earth and Environmental Science. 2020. Vol. 548. 082057 doi:10.1088/1755-1315/548/8/082057.

10. Kuznetsov Y. A.,

Volzhentsev A. V., Kolomeichenko A. V., Kalashnikova L. V. Influence of technological parameters of pseudofluidized layer grain dryer on the grain drying quality. INMATEH: Agricultural Engineering. 2018. Vol. 54, no 1. P. 81-86.

11. Lukaszuk J., Molenda M., Horabik J., Szot B., Montross M. Air flow resistance of wheat bedding as influenced by the filling method. Research in Agricultural Engineering. 2008. Vol. 54, no. 2. P. 50-57.

12. Rogovskii I. L., Titova L. L., Trokhaniak V. I., Solomka O. V., $\quad$ Popyk P.S., S Shvidia V. O., Stepanenko S. P. Experimental studies of drying conditions of grain crops with high moisture content in low-pressure environment. INMATEH. Agricultural Engineering. Bucharest. 2019. Vol. 57. No 1. P. 141-146.

13. Paziuk V. M., Liubin M. V., Yaropud V. M., Tokarchuk O. A., Tokarchuk D. M. Research on the rational regimes of wheat seeds drying. INMATEH: Agricultural Engineering. 2018. Vol. 56, no 3. P. 39-48.

14. Rekas A., Scibisz I., Siger A., Wroniak M. The effect of microwave pre-treatment of seeds on the stability and degradation kinetics of phenolic compounds in rapeseed oil during long-term storage. Food Chemistry. 2017. Vol. 222. P. 43-52.

\section{МОДЕЛЮВАННЯ І РОЗРАХУНОК \\ ЕНЕРГОЗБЕРІГАЮЧИХ РЕЖИМІВ СУШІННЯ ЗЕРНОВИХ МАТЕРІАЛІВ ПІД ДІЄЮ ЕНЕРГЕТИЧНИХ ПОЛІВ В. О. Грищенко}

Анотація. Збереження якості зернових матеріалів при післязбиральної доробки і зберігання в значній мірі залежить від правильно реалізованого процесу сушіння. В агропромисловому виробництві в основному використовують затратні конвекційні зерносушарки. Основна доля непродуктивних затрат енергії приходиться на нагрівання сушильного агенту, частина теплоти якого втрачається в оточуюче середовище через робочі поверхні сушарки i 3 відпрацьованим теплоносієм. Радикальним способом зменшення таких витрат енергії $\epsilon$ зменшення кількості сушильного агенту в процесі до величини необхідної для поглинання та видалення вологи із робочого об'єму сушарки і використання принципів 
адресної «доставки» енергії до висушуємого матеріалу. Останні принципи успішно реалізуються шляхом використання безконтактного підведення енергї̈ електромагнітних полів у вигляді опромінення матеріалу мікрохвильовим або інфрачервоним випромінюванням. В статті розглянуто теоретичні передумови процесів сушіння матеріалу у циклічному режимі 3 інфрачервоним та нагрівом електромагнітним полем надвисокої частоти. Отримані рівняння зміни в часі параметрів зернового матеріалу при нагріванні 3 використанням електромагнітного поля надвисокої частоти або інфрачервоним випромінюванням і при вентилюванні зерна не підігрітим повітрям дозволяють розрахувати процес циклічного сушіння. Сформульовано алгоритм загального розрахунку процесу циклічного сушіння дозволяє визначити раціональні режими проведення процесу, які забезпечують мінімізацію витрат енергії.
Ключові
слова:
ІЧ-нагрів,
НВЧ-нагрів, вентилювання, сушіння зерна, циклічне сушіння.

\section{МОДЕЛИРОВАНИЕ И РАСЧЕТ \\ ЭНЕРГОСБЕРЕГАЮЩИХ РЕЖИМОВ СУШКИ \\ ЗЕРНОВЫХ МАТЕРИАЛОВ ПОД ДЕЙСТВИЕМ ЭНЕРГЕТИЧЕСКИХ ПОЛЕЙ \\ В. А. Грищенко}

Аннотация. Сохранение качества зерновых материалов при послеуборочной доработки и хранения в значительной степени зависит от правильно реализованного процесса сушки. В агропромышленном производстве в основном используют затратные конвекционные зерносушилки. Основная доля непроизводительных затрат энергии приходится на нагрев сушильного агента, часть теплоты которого теряется в окружающую среду через рабочие поверхности сушилки и с отработанным теплоносителем. Радикальным способом уменьшения таких расходов энергии является уменьшение количества сушильного агента в процессе до величины необходимой для поглощения и удаления влаги из рабочего объема сушилки и использования принципов адресной «доставки» энергии до висушуемого материала. Последние принципы успешно реализуются путем использования бесконтактного подвода энергии электромагнитных полей в виде облучения материала микроволновым или инфракрасным излучением. В статье рассмотрены теоретические предпосылки процессов сушки материала в циклическом режиме с инфракрасным и нагревом электромагнитным полем сверхвысокой частоты. Полученные уравнения изменения во времени параметров зернового материала при нагревании с использованием электромагнитного поля сверхвысокой частоты или инфракрасным излучением и при вентилировании зерна не подогретым воздухом позволяют рассчитать процесс циклического сушки. Сформулировано алгоритм общего расчета процесса циклического сушки позволяет определить рациональные режимы проведения процесса, которые обеспечивают минимизацию затрат энергии.
Ключевые слова: ИК-нагрев, ТВЧ-нагрев, вентиляции, сушки зерна, циклическое сушки.

В. О. Грищенко ORCID 0000-0001-7789-3650. 
